\title{
Anticonvulsant effects of aerial parts of Passiflora incarnata extract in mice: involvement of benzodiazepine and opioid receptors
}

\section{Marjan Nassiri-Asl*1, Schwann Shariati-Rad ${ }^{2}$ and Farzaneh Zamansoltani ${ }^{3}$}

\author{
Address: ${ }^{1}$ Department of Pharmacology, School of Medical Sciences, Qazvin University, Qazvin, Iran, ${ }^{2}$ School of Medical Sciences, Qazvin \\ University, Qazvin, Iran and ${ }^{3}$ Department of Anatomy, School of Medical Sciences, Qazvin University, Qazvin, Iran \\ Email: Marjan Nassiri-Asl* - marjan_nassiriaslm@yahoo.com; Schwann Shariati-Rad - drschwann@yahoo.com; \\ Farzaneh Zamansoltani - zamansoltani@gmail.com \\ * Corresponding author
}

Published: 8 August 2007

BMC Complementary and Alternative Medicine 2007, 7:26 doi:10.1 186/1472-6882-7-26

This article is available from: http://www.biomedcentral.com/1472-6882/7/26

(C) 2007 Nassiri-Asl et al; licensee BioMed Central Ltd.

This is an Open Access article distributed under the terms of the Creative Commons Attribution License (http://creativecommons.org/licenses/by/2.0), which permits unrestricted use, distribution, and reproduction in any medium, provided the original work is properly cited.
Received: 5 February 2007

Accepted: 8 August 2007

\begin{abstract}
Background: Passion flower (Passiflora incarnata) is used in traditional medicine of Europe and South America to treat anxiety, insomnia and seizure. Recently, it has shown antianxiety and sedative effects in human.

Methods: In this study, anticonvulsant effects of hydro- alcoholic extract of Passiflora, Pasipay, were examined by using pentylentetrazole model (PTZ) on mice. Pasipay, diazepam, and normal saline were injected intraperitoneally at the doses $0.4-0.05 \mathrm{mg} / \mathrm{kg}, 0.5-1 \mathrm{mg} / \mathrm{kg}$ and $10 \mathrm{ml} / \mathrm{kg}$ respectively 30 minutes before PTZ ( $90 \mathrm{mg} / \mathrm{kg}$, i.p). The time taken before the onset of clonic convulsions, the duration of colonic convulsions, and the percentage of seizure and mortality protection were recorded. For investigating the mechanism of Pasipay, flumazenil ( $2 \mathrm{mg} / \mathrm{kg}$, i.p) and naloxone $(5 \mathrm{mg} / \mathrm{kg}$, i.p) were also injected 5 minutes before Pasipay.

Results: $A_{n} E_{50}$ value of Pasipay in the PTZ model was $0.23 \mathrm{mg} / \mathrm{kg}$ (\%95 CL: 0.156, 0.342). Pasipay at the dose of $0.4 \mathrm{mg} / \mathrm{kg}$ prolonged the onset time of seizure and decreased the duration of seizures compared to saline group $(p<0.00 \mathrm{l})$. At the dose of $0.4 \mathrm{mg} / \mathrm{kg}$, seizure and mortality protection percent were $100 \%$. Flumazenil and naloxone could suppress anticonvulsant effects of Pasipay.

Conclusion: It seems that Pasipay could be useful for treatment absence seizure and these effects may be related to effect of it on GABAergic and opioid systems. More studies are needed in order to investigate its exact mechanism.
\end{abstract}

\section{Background}

Epilepsy is one of the most common serious neurological conditions. In contemporary society, the frequency and importance of epilepsy can hardly be overstated from the epidemiologic studies. However, in most studies, the overall incidence of epilepsy in developed societies has been found to be around 50 cases per 100,000 persons per year, and rises steeply in older age $[1,2]$. The current therapeutic treatment of epilepsy with modern antiepileptic drugs (AEDs) is associated with side-effects, dose-related and chronic toxicity, and teratogenic effects, and approximately $30 \%$ of the patients continue to have seizures with current AEDs therapy $[1,3]$.

Natural products from folk remedies have contributed significantly in the discovery of modern drugs and can be an alternative source for the discovery of AEDs with novel structures and better safety and efficacy profiles [4]. Now, 
various phytochemical and pharmacological studies have been carried out on these anticonvulsant plants [5]. Moreover, the number of patients and medical practitioners in the industrialized world which use herbal medicines as a supplement to or substitute for prescription drugs are increased. Herbal medicines are often considered to be a gentle and safe alternative to synthetic drugs. More than half of the medically important pharmaceutical drugs are either natural products or derivatives of natural products [6-8]. In recent years, some experimental studies have indeed evaluated Medieval Iranian medical remedies using modern scientific methods. These studies raised the possibility of revival of traditional treatments on the basis of evidence-based medicine [9].

In Iran, several herbs have been used for anticonvulsant effects from ancient times [10]. In Iran P. incarnata is prepared by Iran Darouk Pharmaceutical Co. as the form of tablet and drop with the name of Pasipay and is used in the case of nervous disorder, anxiety, insomnia, muscular tension.

The genus Passiflora consists of 500 species that are mostly found in warm and tropical regions. Passiflora comes from Latin word "Passio" that was first time discovered by Spanish discoverers in 1529 and was described as a symbol for "passion of Christ" [11,12]. This plant was used widely in traditional medicine in West India, Mexico, Netherland, South America, Italia and Argentina for treatment of bronchitis, asthma, whooping cough, pneumonia and insomnia. It also has antianxiety, sedative, antispasmodic and mild anti-microbial effects that are known since long time [12]. One of species of this genus named as Passiflora incarnata is more popular than its other species in Europe and in homeopathic medicine; it is used to treat insomnia and anxiety. Passiflora contains several compounds including alkaloids, phenols, glycosyl flavonoids and cyanogenic compounds [12]. In the some experiments, it has potential effects for treatment of some diseases like as anxiety, insomnia, attention- deficit hyperactivity disorder, hypertension and cancer [13-18]. Also, recent study showed that leaves of it had anticonvulsant effects [19].

The effectiveness of Pasipay has been established in treating the physical symptoms of opioid withdrawal in human [20]. But there was no report about the role of opioid system for CNS depressant effects of Passiflora species. Also, there were controversial reports about the role of GABAergic system for CNS effects of it $[21,22]$. In this study we examined anticonvulsant effects of Pasipay using pentylenetetrazole (PTZ) induced seizure as petit mal epilepsy model in mice. It was predicted that Pasipay would show anticonvulsive effects in PTZ model, which may be due to several mechanism. Thus, we elucidated the possi- ble mechanisms underlying the actions of Pasipay on the CNS and assessed the probable involvement of GABAergic and opioid system.

\section{Methods \\ Animal}

Male BALB/c mice (25-30 g) were obtained from the Razi Institute (Karaj, Iran). The animals were individually housed in colony rooms with $12 / 12 \mathrm{~h}$ light/dark cycle at $21 \pm 2^{\circ} \mathrm{C}$ and had free access to food and water. All animal experiments were carried out in accordance with the regulations of the Ethics Committee of the Qazvin University of Medical Sciences.

\section{Plant material}

Hydro- alcoholic extract of Pasipay was obtained from Iran Darouk Pharmaceutical Co. (Tehran, Iran) which was prepared from the standardized extract of leaves, flower and fruit of $P$. incarnata. The total flavonoid content in hydro- alcoholic extracts related to the dried plant material was $4 \%(\mathrm{w} / \mathrm{w})$ including vitexin and rutin.

\section{Chemicals}

Drugs used as follows: PTZ (Sigma), flumazenil ampoule (2 $\mathrm{mg} / \mathrm{kg}$ ) (Roche), diazepam (Chemidaru, Iran), naloxone (Tolid Daru, Iran). PTZ, diazepam and naloxone were dissolved in normal saline. All compounds were prepared freshly each time and administered intraperitoneally.

\section{Anticonvulsant activity}

\section{PTZ-induced seizure}

The mice were divided into groups of ten animals each. In the four groups, the mice were given Pasipay at the doses $(0.05,0.1,0.2,0.4 \mathrm{mg} / \mathrm{kg}$ i.p.) $30 \mathrm{~min}$ before the administration of PTZ ( $90 \mathrm{mg} / \mathrm{kg}$ i.p). Two groups were injected diazepam $(0.5,1 \mathrm{mg} / \mathrm{kg}$ i.p.) and one group was injected normal saline $30 \mathrm{~min}$ before the administration of PTZ $(90 \mathrm{mg} / \mathrm{kg}$ i.p.) [23]. Each animal is placed into an individual plastic cage for observation lasting $1 \mathrm{~h}$. The onset of a general clonus was used as the endpoint. The general clonus was characterized by forelimb clonus followed by full clonus of the body. The time taken before the onset of clonic convulsions, the duration of clonic convulsions, and the percentage of seizure and mortality protection were recorded [23].

The effect of flumazenil on the anticonvulsant activity of Pasipay We also studied the effects of a selective benzodiazepine receptor antagonist, flumazenil on the anticonvulsant activity of Pasipay in order to investigate the probable involvement of benzodiazepine receptors [24]. It was selected six groups of ten mice each. In the first group, mice were given flumazenil $(2 \mathrm{mg} / \mathrm{kg}) 5 \mathrm{~min}$ before the administration of Pasipay $(0.4 \mathrm{mg} / \mathrm{kg})$ and $35 \mathrm{~min}$ before 
the injection of PTZ. In the second group, the animals received flumazenil $(2 \mathrm{mg} / \mathrm{kg}) 5 \mathrm{~min}$ before the administration of diazepam $(0.5 \mathrm{mg} / \mathrm{kg})$. Also, three groups were injected diazepam (0.5 mg/kg i.p.), flumazenil ( $2 \mathrm{mg} / \mathrm{kg})$ and normal saline $30 \mathrm{~min}$ before the administration of PTZ $(90 \mathrm{mg} / \mathrm{kg}$ i.p.) respectively [23-26]. The anticonvulsant activity of Pasipay and diazepam in mice pretreated with flumazenil was assessed and compared with normal saline $(10 \mathrm{ml} / \mathrm{kg})$, flumazenil $(2 \mathrm{mg} / \mathrm{kg})$, diazepam $(0.5$ $\mathrm{mg} / \mathrm{kg})$ and Pasipay $(0.4 \mathrm{mg} / \mathrm{kg})$ treated animals.

The effect of naloxone on the anticonvulsant activity of Pasipay It was selected four groups of ten mice each for further investigation the probable modulatory activities of opioid receptors on the anticonvulsant activity of Pasipay $[27,28]$. It was applied naloxone as an opioid receptor antagonist at a dose of $(5 \mathrm{mg} / \mathrm{kg}) 5 \mathrm{~min}$ before the administration of Pasipay $(0.4 \mathrm{mg} / \mathrm{kg})$ and $35 \mathrm{~min}$ before the injection of PTZ in group of ten mice each [23-26]. The anticonvulsant activity of Pasipay in groups pretreated with naloxone was assessed and compared with animals pretreated only with Pasipay $(0.4 \mathrm{mg} / \mathrm{kg})$, naloxone (5 $\mathrm{mg} / \mathrm{kg}$ ) and normal saline $(10 \mathrm{ml} / \mathrm{kg})$ groups.

\section{Statistical analysis}

The dose of Pasipay to produce an anticonvulsant (ED50) effect in $50 \%$ of animals and its associated 95\% confidence limits was calculated by Litchfield and Wilcoxon methods (PHARM/PCS Version 4). The data were expressed as mean values \pm S.E.M. and tested with oneway ANOVA followed by the multiple comparison test of Tukey-Kramer. Results with $\mathrm{p}<0.05$ were taken significant.

\section{Results}

\section{PTZ-induced seizure}

An $\mathrm{ED}_{50}$ value of Pasipay in the PTZ model was $0.2 \mathrm{mg} / \mathrm{kg}$ (\%95 CL: $0.156,0.342$ ). Pasipay at the dose of $0.4 \mathrm{mg} / \mathrm{kg}$ prolonged the onset time of seizure and decreased the duration of seizures compared to saline group ( $\mathrm{p}<0.001)$ (Table 1). Pasipay at the dose of $0.2 \mathrm{mg} / \mathrm{kg}$ only pro- longed the onset time of seizure, compared to saline group ( $\mathrm{p}<0.001)$ (Table 1$)$. As it is shown in Table 1 , Pasipay exhibited its protection against seizure in a dosedependent manner. Furthermore, diazepam prolonged the latency and shortened the duration of seizures compared to saline group (Table 1).

\section{The effect of flumazenil on the anticonvulsant activity of Pasipay}

In the PTZ-induced seizure model, the administration of flumazenil ( $2 \mathrm{mg} / \mathrm{kg}) 5 \mathrm{~min}$ before Pasipay $(0.4 \mathrm{mg} / \mathrm{kg})$ reversed the effect of Pasipay in prolonging seizure latency and reducing the duration of clonic seizures. There was no significant difference between the latency and duration of seizure in mice which received Pasipay $(0.4 \mathrm{mg} / \mathrm{kg})$ pretreated with flumazenil and the saline group. Also, flumazenil could reverse the anticonvulsant activity of diazepam (Table 2).

\section{The effects of naloxone on the anticonvulsant activity of Pasipay}

Pretreatment of mice with naloxone $(5 \mathrm{mg} / \mathrm{kg}) 5 \mathrm{~min}$ before the administration of the Pasipay $(0.4 \mathrm{mg} / \mathrm{kg})$ reversed the reduction in seizure duration. However, the time course of the seizure threshold in mice was not reversed completely by naloxone and it was significant compared to control ( $\mathrm{p}<0.001)$ (Table 3).

\section{Discussion}

The present study investigated the anticonvulsant effect of Pasipay using the PTZ-model. Pasipay could suppress onset and duration of clonic seizure in PTZ model and it seems that this effect increased dose dependently. Also seizure and mortality protection percent increased dose dependently as we could observe that at the dose of 0.4 $\mathrm{mg} / \mathrm{kg}$, all animals were protected against seizure and mortality significantly and this effect was similar to diazepam $1 \mathrm{mg} / \mathrm{kg}$.

This study is in agreement with a recent report by Dhawan et al, however, we have seen anticonvulsant effects of

Table I: Effects of Pasipay on PTZ-induced convulsion in mice

\begin{tabular}{|c|c|c|c|c|}
\hline Treatment (dose) & Onset (sec) & Duration (sec) & Seizure protection (\%) & $\begin{array}{c}\text { Mortality protection } \\
(\%)\end{array}$ \\
\hline Normal saline $(10 \mathrm{ml} / \mathrm{kg})$ & $51.83 \pm 64$ & $12 \pm 1.80$ & 0 & 0 \\
\hline Diazepam $(0.5 \mathrm{mg} / \mathrm{kg})$ & $485.5 \pm 74.97 * * *$ & $3.5 \pm 2.21^{*}$ & 80 & 90 \\
\hline Diazepam (I mg/kg) & $600 \pm 0 * * *$ & $0 \pm 0 * * *$ & 100 & 100 \\
\hline Pasipay $(0.05 \mathrm{mg} / \mathrm{kg})$ & $56 \pm 4.51$ & $15.3 \pm 4.48$ & 0 & 0 \\
\hline Pasipay $(0.1 \mathrm{mg} / \mathrm{kg})$ & $112.66 \pm 16.2$ & $7.1 \pm 2.5$ & 10 & 50 \\
\hline Pasipay $(0.2 \mathrm{mg} / \mathrm{kg})$ & $137.6 \pm 17.8^{* * * *}$ & $7 \pm 1.1$ & 20 & 80 \\
\hline Pasipay (0.4 mg/kg) & $600 \pm 0 * * *$ & $0 \pm 0 * * *$ & 100 & 100 \\
\hline
\end{tabular}

Normal saline, diazepam and Pasipay were administered i.p. $30 \mathrm{~min}$ before the injection of PTZ $(90 \mathrm{mg} / \mathrm{kg}$, i.p.); Values are the mean \pm S.E.M. for 10 mice. ${ }^{*} \mathrm{p}<0.05$; $* * * \mathrm{p}<0.001$, compared to saline group, Tukey-Kramer test. 
Table 2: Effect of flumazenil on the anticonvulsant activity of Pasipay and diazepam in PTZ-induced convulsion in mice

\begin{tabular}{cccc}
\hline Treatment (dose) & Onset (sec) & Duration (sec) & Mortality protection (\%) \\
\hline Normal saline (10 ml/kg) & $51.83 \pm 64$ & $12 \pm 1.80$ & 0 \\
Flumazenil $(2 \mathrm{mg} / \mathrm{kg})$ & $44.71 \pm 1.44$ & 8.25 & 85 \\
Diazepam $(0.5 \mathrm{mg} / \mathrm{kg})$ & $485.5 \pm 74.97^{* * *}$ & $3.5 \pm 2.21^{*}$ & 90 \\
Diazepam+ Flumazenil & $152.5 \pm 28.9$ & $12.25 \pm 3.42$ & 70 \\
Pasipay (0.4 mg/kg) & $600 \pm 0 * * *$ & $0 \pm 0 * * *$ & 100 \\
Pasipay+ Flumazenil & $184.33 \pm 29.1$ & $11 \pm 1.52$ & 50 \\
\hline
\end{tabular}

Normal saline, diazepam and Pasipay were administered (i.p.) $30 \mathrm{~min}$ before the PTZ ( $90 \mathrm{mg} / \mathrm{kg}$, i.p.); Flumazenil was administered $35 \mathrm{~min}$ before the injection of PTZ $\left(90 \mathrm{mg} / \mathrm{kg}\right.$, i.p.); Values are the mean \pm S.E.M. for 10 mice; $*_{p}<0.05$; $*^{* * *} p<0.001$, compared with saline group, Tukey-Kramer test.

extract at the lower doses. This could be explained by several reasons: Our extract was the standard hydroalcoholic extract of aerial parts of herb which was prepared as the drug formulation, Pasipay, by Iran Darouk Pharmaceutical Co. But, the previous work was the methanolic extract of the leaves of Passiflora incarnata [19]. Moreover, there are several controversial reports about the CNS effects of $P$. incarnata extracts and their active component which could be related to different active component of it [2933]. Meanwhile, in our study, the major flavonoids of Pasipay were also different from previous studies. In addition, there is a different between the sources of $P$. incarana of our work and previous work.

Clonic seizure was induced by $\gamma$-aminobutyric acid (GABA) transmission blocker PTZ [34]. Regarding the possible contribution of GABAergic system in the anticonvulsant activity of Pasipay, flumazenil, a benzodiazepine receptor antagonist, was used [24]. As it was shown in table 2, flumazenil decreased the prolongation of seizure latency induced by Pasipay and it also antagonized the effect of Pasipay on decreasing the duration of clonic seizures in the PTZ model. It is noteworthy that the anticonvulsant effect of Pasipay is blocked by an antagonist of benzodiazepine receptor. So this effect of Pasipay seems to be related to benzodiazepine receptor activation. This result is similar to previous finding by Fernandez et al [21]. They found that anxiolytic effects of one component of Passiflora were related to benzodiazepine receptors activation. However, there is a controversial study which reported that anxiolytic effects of $P$. incarnata extract were not mediated through an action on the benzodiazepine/ GABA receptors [22]. On the other hand, it is found that many flavonoids could act as benzodiazepine- like molecules in the central nervous system (CNS) and modulate GABA-generated chloride currents in animal models of anxiety, sedation and convulsion [21]. It is possible that anticonvulsant activities of Pasipay related to its flavonoids like rutin and vitexin as was determined in the Pasipay. Recently, rutin had sedative and sleep- enhancing effects in mice [21]. However, there is a controversial study which reported that pure vitexin and isovitexin of $P$. incarnata had no activity in CNS tests [35]. Further studies need to make clear which of these flavonoids or other compounds have anticonvulsant effects.

We also found other mechanism about the anticonvulsant effects of Pasipay. As it was shown in table 3, naloxone only antagonized the effect of Pasipay on decreasing the duration of clonic seizures in the PTZ model compared to saline group. Naloxone decreased the prolongation of seizure latency induced by Pasipay. However, it did not show any significant reversal of Pasipay effects. It seems that some part of anticonvulsant effects of it related to activation of opioid system which was attenuated by naloxone. Since, one study reported that concurrent co-administration of benzoflavon moiety of $P$. incarnata with morphine attenuated naloxone-precipitated withdrawal jumps [12]. Thus, we used naloxone as a non-specific opioid receptor antagonist for preliminary study to clear the exact mechanism of this herb.

On the other hand, anticonvulsant activity of kappa opioid receptor (KOPr) agonists has been established in wide range of previous animal studies. KOPr agonists are effective against bicuculline-, maximal electroshock- and exci-

Table 3: Effect of naloxone on the anticonvulsant activity of Pasipay in PTZ-induced convulsion in mice

\begin{tabular}{cccc}
\hline Treatment (dose) & Onset (sec) & Duration (sec) & Mortality protection (\%) \\
\hline Normal saline $(10 \mathrm{ml} / \mathrm{kg})$ & $51.83 \pm 64$ & $12 \pm 1.80$ & 0 \\
Naloxone $(5 \mathrm{mg} / \mathrm{kg})$ & $10.66 \pm 0.66$ & $49.6 \pm 4.34$ & 0 \\
Pasipay $(0.4 \mathrm{mg} / \mathrm{kg})$ & $600 \pm 0 * * *$ & $0 \pm 0 * * *$ & 100 \\
Pasipay+ Naloxone & $125.4 \pm 2.87^{* * * *}$ & $8.81 \pm 2.64$ & 40
\end{tabular}

Normal saline and Pasipay were administered (i.p.) $30 \mathrm{~min}$ before the injection of PTZ ( $90 \mathrm{mg} / \mathrm{kg}$, i.p.); Naloxone was administered $35 \mathrm{~min}$ before the injection of PTZ ( $90 \mathrm{mg} / \mathrm{kg}$, i.p.); Values are the mean \pm S.E.M. for 10 mice; $* * * \mathrm{p}<0.001$, compared to saline group, Tukey-Kramer test. 
tatory amino acid-induced convulsions. Furthermore, they attenuate the kindling of seizures produced by repeated administration of PTZ [36-39]. Furthermore, dynorphine, an endogenous opioid peptide, binds to KOPr. It has anticonvulsant effects in previous studies [28]. There is one hypothesis that Pasipay could active KOPr and produce protective effects against PTZ-induced seizure. However, the mechanism of anticonvulsant effects with KOPr agonist, have not been universal. Modulatory effects of its agonist on seizure induced by $\mathrm{GABA}_{\mathrm{A}}$ receptor antagonists were reported [36]. Furthermore, its agonist could inhibit glutamate release [40,41]. Thus, there are two possibilities which could explain the anticonvulsant activity of the Pasipay via the KOPr activation: 1) enhancement GABAergic activity or 2) attenuation glutamatergic activity.

\section{Conclusion}

In brief, the present study provides evidence for anticonvulsant activity of Pasipay in the clonic seizure of PTZ model. As the protective effects of Pasipay in clonic seizure it suggests that it could be useful for treatment of absence seizure. Furthermore, the important role of benzodiazepine receptor in the effects of Pasipay should be considered.

Also, the opioid receptor mechanism is apparently involved in the response induced by Pasipay which should be investigated.

\section{Competing interests}

The author(s) declare that they have no competing interests.

\section{Authors' contributions}

MNA is the primary author and wrote the manuscript, participated in the design of the study and performed the statistical analysis and revised the manuscript. SSR and FZ helped in the design of the study and wrote the manuscript. All of the authors have read and approved the final manuscript.

\section{Acknowledgements}

The authors are thankful to Iran Darouk Pharmaceutical Co. (Tehran, Iran) for giving extract and certification analysis of $P$. incarnata.

\section{References}

I. Poole K, Moran N, Bell G, Solomon J, Kendall S, McCarthy M, McCormick D, Nashef L, Johnson A, Sander J, Shorvon S: Patients' perspectives on services for epilepsy: a survey of patient satisfaction, preferences and information provision in 2394 people with epilepsy. Seizure 2000, 9(8):55I-558.

2. Ropper AH, Brown RH: Epilepsy and other seizures disorder. In Adams and Victor's Principles of Neurology 8th edition. Edited by: Ropper AH, Brown RH. New York: McGraw-Hill; 2005:27I-297.

3. Samren EB, van Duijn CM, Koch S, Hiilesmaa VK, Klepel H, Bardy AH, Mannagetta GB, Deichl AW, Gaily E, Granstrom ML, Meinardi H, Grobbee DE, Hofman A, Janz D, Lindhout D: Maternal use of antiepileptic drugs and the risk of major congenital malfor- mations: a joint European prospective study of human teratogenesis associated with maternal epilepsy. Epilepsia 1997, 38(9): $981-990$.

4. Raza M, Shaheen F, Choudhary MI, Rahman AU, Sombati S, Suria A Rafiq A, DeLorenzo RJ: Anticonvulsant effect of FS-I subfraction isolated from roots of Delphinim Denudatum on hippocampal pyramidal neurons. Phytotherapy Res 2003, I 7(I):38-43.

5. Nsour WM, Lau CB, Wong IC: Review on phytotherapy in epilepsy. Seizure 2000, 9(2):96-107.

6. Sucher NJ: Insights from molecular investigations of traditional Chinese herbal stroke medicines: Implications for neuroprotective epilepsy therapy. Epilepsy Behav 2006, 8(2):350-362.

7. Koehn FE, Carter GT: The evolving role of natural products in drug discovery. Nat Rev Drug Discov 2005, 4(3):206-220.

8. Newman DJ, Cragg GM, Snader KM: Natural products as sources of new drugs over the period 198I-2002. J Nat Prod 2003, 66(7): 1022-1037.

9. Gorji A, Khaleghi Ghadiri M: History of epilepsy in Medieval Iranian medicine. Neurosci Biobehav Rev 200I, 25(5):455-46I.

10. Zargari A: Medicinal plants Tehran: Tehran University; 1989.

II. Kinghorn GR: Passion, stigma, and STI. Sex Transm Inf 200I, 77(5):370-375.

12. Dhawan K, Dhawan S, Sharma A: Passiflora: a review update. J Ethnopharmacol 2004, 94(I): I-23.

13. Akhondzadeh S, Naghavi HR, Vazirian M, Shayeganpour A, Rashidi H, Khani M: Passionflower in the treatment of generalized anxiety disorder: a pilot double-blind randomized controlled trial with oxazepam. J Clin Pharm Ther 200I, 26(5):363-367.

14. Reginatto FH, De-Paris F, Petry RD, Quevedo J, Ortega GG, Gosmann G, Schenkel EP: Evaluation of anxiolytic activity of spray dried powders of two South Brazilian Passiflora species. Phytother Res 2006, 20(5):348-35I.

15. Wheatley D: Medicinal plants for insomnia: a review of their pharmacology, efficacy and tolerability. J Psychopharmacol 2005, I9(4):4|4-42I.

16. Akhundzadeh S, Mohammadi MR, Momeni F: Passiflora incarnata in treatment of attention-deficit hyperactivity disorder in children and adolescents. Therapy 2005, 2(4):609-6I4.

17. Ichimura T, Yamanaka A, Ichiba T, Toyokawa T, Kamada Y, Tamamura T, Maruyama S: Antihypertensive effect of an extract of Passiflora edulis rind in spontaneously hypertensive rats. Biosci Biotechnol Biochem 2006, 70(3):718-72I.

18. Rowe CA, Nantz MP, Deniera C, Green K, Talcott ST, Percival SS: Inhibition of neoplastic transformation of benzo[alpha]pyrene-treated BALB/c 3T3 murine cells by a phytochemical extract of passionfruit juice. J Med Food 2004, 7(4):402-407.

19. Dhawan K, Kumar S, Sharma A: Evaluation of central nervous system effects of Passiflora incarnata in experimental animals. Pharmaceutical Biology 2003, 4 I (2):87-9I.

20. Akhondzadeh S, Kashani L, Mobaseri M, Hosseini SH, Nikzad S, Khani $M$ : Passionflower in the treatment of opiates withdrawal: a double-blind randomized controlled trial. J Clin Pharm Ther 200I, 26(5):369-373.

21. Fernandez SP, Wasowski C, Loscalzo LM, Granger RE, Johnston GA, Paladini AC, Marder M: Central nervous system depressant action of flavonoid glycosides. Eur J Pharmacol 2006, 539(3): I68-I76.

22. Soulimani R, Younos C, Jarmouni S, Bousta D, Misslin R, Mortier F: Behavioural effects of Passiflora incarnata $L$. and its indole alkaloid and flavonoid derivatives and maltol in the mouse. J Ethnopharmacol 1997, 57(I): I I-20.

23. Vogel HG, Vogel WH: Drug Discovery and Evaluation, Pharmacological Assay Berlin: Springer; 1997.

24. File SE, Pellow S: Intrinsic actions of the benzodiazepine receptor antagonist Ro I 5-I 788. Psychopharmacology I 986, 88(I): I-I I.

25. Hosseinzadeh H, Parvardeh S: Anticonvulsant effects of thymoquinone, the major constituent of Nigella sativa seeds, in mice. Phytomedicine 2004, I I ( I):56-64.

26. Hosseinzadeh H, Parvardeh S, Nassiri-AsI M, Mansouri MT: Intracerebroventricular administration of thymoquinone, the major constituent of Nigella sativa seeds, suppress epileptic seizures in rats. Med Sci Monit 2005, I I (4):BR I 06-IIO.

27. Lauretti GR, Ahmad I, Pleuvry BJ: The activity of opioid analgesics in seizure models utilizing $\mathbf{N}$-methyl-D-aspartic acid, kainic 
acid, bicuculline and pentylenetetrazole. Neuropharmacology 1994, 33(2): 155-160.

28. Kaminski RM, Witkin JM, Shippenberg TS: Pharmacological and genetic manipulation of kappa opioid receptors: Effects on cocaine- and pentylenetetrazol-induced convulsions and seizure kindling. Neuropharmacology 2007, 52(3):895-903.

29. Shinomiya K, Inoue T, Utsu Y, Tokunaga S, Masuoka T, Ohmori A, Kamei C: Hypnotic activities of chamomile and Passiflora extracts in sleep-disturbed rats. Biol Pharm Bull 2005, 28(5):808-8I0.

30. Dhawan K, Kumar S, Sharma A: Anti-anxiety studies on extracts of Passiflora incarnata Linneaus. J Ethnopharmacol 200I, 78(23): $165-170$.

31. Zanoli P, Avallone R, Baraldi M: Behavioral characterisation of the flavonoids apigenin and chrysin. Fitoterapia 2000, 7 I(Suppl I):SII7-SI23.

32. Muller SD, Vasconcelos SB, Coelho M, Biavatti MW: LC and UV determination of flavonoids from Passiflora alata medicinal extracts and leaves. J Pharm Biomed Anal 2005, 37(2):399-403.

33. Dhawan $K$, Kumar S, Sharma A: Comparative anxiolytic activity profile of various preparations of Passiflora incarnata linneaus: a comment on medicinal plants standardization. J Altern Complement Med 2002, 8(3):283-29I.

34. Riazi K, Honar H, Homayoun H, Rashidi N, Deghani M, Sadeghipour $H$, Gaskari SA, Dehpour AR: Sex and esterus cycle differences in the modulatory effects of morphine on seizure susceptibility in mice. Epilepsia 2004, 45(9): $1035-1042$.

35. Speroni E, Minghetti A: Neuropharmacological activity of extracts from Passiflora incarnata. Planta Med 1988, 54(6):488-49I.

36. Yajima $Y$, Narita M, Takahashi-Nakano $Y$, Misawa M, Nagase $H$, Mizoguchi $H$, Tseng LF, Suzuki T: Effects of differential modulation of $\mu-, \delta$ - and $\kappa$-opioid systems on bicuculline-induced convulsions in the mouse. Brain Res 2000, 862(I-2): 120-126.

37. Manocha A, Mediratta PK, Sharma KK: Studies on the anticonvulsant effect of U50488H on maximal electroshock seizure in mice. Pharmacol Biochem Behav 2003, 76(I): III-II7.

38. VonVoigtlander PF, Hall ED, Ochoa MC, Lewis RA, Triezenberg HJ: U-54494A: a unique anticonvulsant related to kappa opioid agonists. J Pharmacol Exp Ther 1987, 243(2):542-547.

39. Becker A, Braun H, Schroder H, Grecksch G, Hollt V: Effects of enadoline on the development of pentylenetetrazol kindling, learning performance, and hippocampal morphology. Brain Res 1999, 823(1-2):191-197.

40. Rawls SM, McGinty JF: Kappa receptor activation attenuates Ltrans- pyrrolidine-2, 4-dicarboxylic acid-evoked glutamate levels in the striatum. J Neurochem 1998, 70(2):626-634.

4I. Wagner J], Caudle RM, Chavkin C: Kappa-opioids decrease excitatory transmission in the dentate gyrus of the guinea pig hippocampus. J Neurosci 1992, I 2:132-141.

\section{Pre-publication history}

The pre-publication history for this paper can be accessed here:

http://www.biomedcentral.com/1472-6882/7/26/prepub

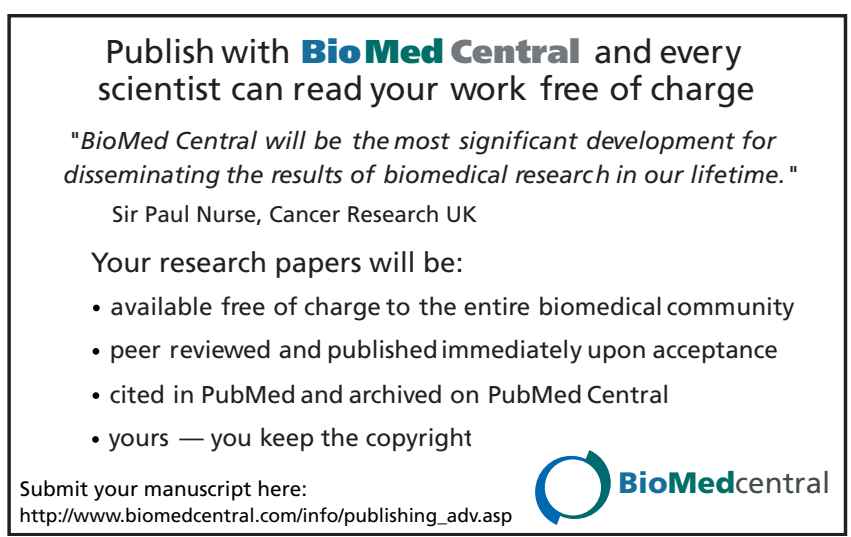

